\title{
Some Aspects of the Baltic Countries' Pre- and Post- Accession Convergence to the European Union
}

\author{
Mait Talts \\ Department of International Relations, \\ Tallinn University of Technology \\ Akadeemia tee 3-256 \\ Tallinn 12618, Estonia \\ E-mail: mait.talts@ttu.ee
}

\begin{abstract}
This comprehensive article provides an overview of the broader process of political, legal and societal changes characterizing the Baltic countries' convergence towards the European Union. The article aims to identify the specific areas and issues which reveal both similarities and differences between the three Baltic countries. Special focus has been given to issues of economic development, economic policy choices, employment, public opinion and some legal aspects. The article, first of all, tries to reveal the differences between Estonia, Latvia and Lithuania stemming from different economic policy decisions made by the Baltic countries in the 1990s as well as from to the fact that in 1997-1999 the European Union treated the Baltic countries somewhat differently in terms of conditionality. However, during the $21^{\text {st }}$ century, especially due to the economic recession, the 'Baltic clocks' have been synchronized despite the obvious differences in political system and levels of economic development. The author of the current article believes that the main factor behind that development was the convergence to European Union.
\end{abstract}

Keywords: accession, Baltic States, convergence, economic policy, economic recession of 2008-2011, Estonia, European Union, Latvia, Lithuania, public opinion, unemployment

The Baltic countries' pre- and post-accession development in regard to the EU is not a totally unstudied area. Numerous single studies have been conducted, a considerable number of articles and some significant books have been published, but the majority of them usually focuses on merely one of the Baltic States. 
However, more comprehensive generalizations and genuinely comparative studies comprising developments in all three Baltic countries have begun to emerge just recently (e.g., Smith et al., 2002; Van Elsuwege, 2008; Kasekamp, 2010; EHDR, 2011). The current article also tries to compare the political, economic and social developments in Estonia, Latvia and Lithuania on the broader retrospective scale before and after the actual EU accession in order to reveal some issues, trends and shifts that have been not taken sufficiently into consideration.

The Baltic countries have been usually seen from outside as a single geopolitical area despite the fact that the countries themselves have tried to emphasize the differences ever since 1991. There is no doubt that sufficient cultural distinctions exist between Estonia, Latvia and Lithuania. In the context of the convergence to the European Union and ultimately the financial crisis of 2008-2011 the Baltic countries have been forced to adopt quite similar economic and social policy solutions. The current paper tries to show in some detail how the Baltic countries have become more similar in the sense of economic policy, societal and public opinion trends despite the persistent different levels of social welfare, culture and political system.

\section{Background}

In the early 1990s, Estonia, Latvia and Lithuania restored their independence after decades of Soviet occupation. Estonia and Latvia chose to strictly follow the path of legal continuity ("restoration of independence"). Upon the declaration of independence of the Republic of Lithuania on 12 March 1990, the declaration, expressis verbis, suggested the restoration of independence, but the act itself was implicitly based upon the inalienable right to self-determination and the right declared in the Soviet Union Constitution to "secede from the Union". Therefore, in 1991, Lithuania became de facto independent after the moratorium it applied to the declaration of independence and emerged as a new country with new boundaries and citizen population. Whereas clear reference was made only to the Helsinki Final Act of the Conference of Security and Cooperation in Europe (CSCE) and not explicitly to restoring the status quo ante, as was the case in the other Baltic countries (Van Elsuwege, 2008, p. 83).

In Estonia, a representative body of the pre-occupation period legitimized citizen population-Eesti Kongress - was selected for the restoration of independence, which in cooperation with the last Supreme Council of Soviet Estonia, elected 
under Soviet jurisdiction but already in the new situation of political pluralism, established a new Constitutional Assembly to carve out the new Constitution by 1992. Latvia chose not to select such a representative body after the restoration of independence and their unique historical situation made it possible to enforce the original 1922 Constitution (Kasekamp, 2011, pp. 216-217), which has been later amended on several occasions.

The described legal differences in the restoration of independence in the Baltic region did not generate a principally different attitude towards the Baltic countries from the part of the EU, its main Member States or other Western countries (particularly the US). At least since the collapse of the Soviet Union, the "Baltic issue" has been unanimously regarded by the Western countries as a "special issue" (largely owing to the US and other countries' policy of nonrecognition of the Soviet occupation) and since 1991 it has been approached as separate from other countries which restored independence after the Soviet Union's collapse (e.g., the Ukraine or Georgia). As a result, the legitimized right of the Baltic States to restore their independence was recognized by other countries and also by many international organizations, in which the Baltic countries simply reinstated their member status.

Already since 1989, the European Community has regarded the former Soviet satellite countries, the developing new democracies in Central and Eastern Europe as their potential strategic "backcountry" and, in the long run, one of the most important factors in the Union's enlargement and in consolidating the Common Market. Around the same time the implementation of the PHARE programme was prepared and the Baltic countries with other Central and EastEuropean countries (CEEC) later joined. The juxtaposition of the Baltic States with other CEECs (and not only with other successors of the Soviet Union) was thus no longer an issue for the Western world after 1991. The first sign of the EU's changed attitude and not seeing the Baltic countries "as successors of the former Soviet Union" is the fact that the European Commission decided not to include the Baltic countries in the TACIS programme, which was implemented in December 1991 to assist members of the Commonwealth of Independent States (Van Elsuwege, 2008, p. 103). In the instrumental phase of convergence to the EU, when accession talks were already on the agenda, the issues of differentiation between the Central and East-European (including the Baltic) countries were nevertheless raised.

Among the main concerns of the Western countries was (and has been) the presence of a large foreign population compared to the indigenous population of Estonia and Latvia in the post-occupation period and this was, quite justly, 
seen as a critical source of instability, even if somewhat overestimated at times. These were Russian-speaking people who had settled in the Baltic States during the years of occupation (see Katus, Puur \& Sakkeus, 2002). After all, the early 1990s were a time when ethnic conflicts flared in former Yugoslavia and the territory of the former Soviet Union, and elements of conflict were certainly present in the Baltic region. The first European Parliament reports on the situation in the Baltics (e.g., the one by Gary Titley from December 1992) were relatively critical (Van Elsuwege, 2008, pp. 108-109). However, immediately after the European Council's Copenhagen Summit in June 1993 (at which the socalled Copenhagen criteria for new member countries were laid down) political consensus was achieved and the European Parliament started to support the view that the issue of the presence of Russian troops in the Baltic countries cannot be tied to the situation of the Russian-speaking population in these countries (Van Elsuwege, 2008, pp. 111-112). And yet, largely owing to the situation in the Baltic countries, all new agreements were added the so-called "Baltic clause", which directly indicated the need to safeguard democratic principles and human rights and stipulated sanctions for potential violation of these principles. Since similar clauses were included in the then European Community agreements with Slovenia and Albania, Peter Van Elsuwege (2008, p. 107) argues, this was a reflection of the political situation of the period (in Yugoslavia and Haiti) rather than anything else.

To build a functioning market economy and ensure general modernization, the convergence to the EU was virtually the only possible development alternative for the newly independent Baltic countries. At the beginning of the 1990s after the disappearance of the once unified Eastern market, mostly Finland and Sweden who were very close to accession and Denmark and Germany, who were already members, became the new target countries for the export and reexport (transit), which formed the foundation of these countries' economies. By 1995, export from the EU countries constituted 65 per cent of the total export to Estonia, in Latvia the percentage was 45 and in Lithuania 37, respectively (Grabbe \& Hughes, 2000, p. 15).

Another problem that needed to be resolved was the security of the Baltic countries in what was feared to become a security vacuum (in terms of security policies in the "grey area" between the East and the West). Aside from NATO membership, European Union was seen as an additional security guarantee both by the political elite and by popular opinion (Ruutsoo et al., 1998, p. 14). Of course, the European Union was not a substitute for NATO. The popularity of the European Union in Estonia (and possibly in other Baltic countries) was enhanced by the fact that without EU membership, Estonia would have had little 
chance to join NATO. The fortuitous historical moment had to be seized and also gave meaning to former President of Estonia Lennart Meri's constant reminding that "we are permanently short of time" (see Meri, 1996).

At the same time, the Baltic countries' relations with the European Community/ Union in the 1990s and later by no means developed in a simple and unproblematic course, as has been later claimed with political motivation. According to Klaudius Maniokas, "the Baltic-EU relations did not follow the principle of simple linear logic" and were accompanied by certain "instability, uncertainty about further steps and rather radical changes with respect to the geopolitical scope of enlargement" (Maniokas, 2005, pp. 19-20). In fact, this applies to both the pre-accession talks' period and the negotiations itself (see Raig, 2008, pp. 81-97).

The process even created significant tension between the Baltic countries, especially after the European Commission adopted Agenda 2000 in summer 1997, and in December the same year the European Council of Luxembourg invited Estonia to accession talks, excluding Latvia and Lithuania.

\section{Actual convergence}

Immediately after the restoration of independence in 1991, several Lithuanian politicians in the framework of the Baltic Assembly tried to spread the idea of establishing a union of Baltic countries, a kind of "Baltic Benelux", and then make a joint effort to accede to the European Community/Union (see Päevaleht, 1991). Estonian politicians, in particular, strongly opposed to this proposal, mostly because they feared that this could have an adverse effect to the accession prospects of Estonia, Latvia and Lithuania. Since 1992, the Baltic countries started to make attempts to establish contacts with the EU separately, but coordinating the steps along the way.

The first agreements signed by the European Community/Union and the newly independent Baltic countries were trade and cooperation agreements, announced by the European Commission on 4 November 1991 and accompanied by a political Joint Declaration (Van Elsuwege, 2008, p. 105). Already in February 1994 preparations were made to draft association agreements, which were to replace free trade agreements "as soon as possible" (Van Elsuwege, 2008, p. 129). The agreements were ready to be signed in April 1995, were signed by the Baltic countries on 12 June 1995, but came into force only after their final ratification 
by all former Member States in February 1998. In late autumn 1995, the Baltic States handed over official applications to accede to the European Union (Latvia on 13 October, Estonia on 28 November, and Lithuania on 11 December 1995).

During the period from 1995 to 1999, the European Union tried to resolve the important principles and technicalities of the upcoming Eastern Enlargement, which raised the issue of the inevitability of institutional reforming of the union. At the European Council in December 1995 in Madrid it became clear that accepting all applicant countries would prove technically overwhelming for the European Union. While Germany would have preferred the integration of only three candidate countries-Poland, Hungary and the Czech Republic-France fought to get even the clearly backward Bulgaria and Romania involved in the accession process. There were debates about different negotiation strategies, such as the "regatta" and the "stadium", but it became clear that individual approach to the candidate countries would not be applicable. At the time, neither Estonia nor Lithuania argued against such individual approach, the former hoping to gain a better starting platform for accession with economic success, compared to its Baltic partners, and the latter because the problem of Russian minority was considerably milder in Lithuania. So Latvia, who lacked an influential foreign political spokescountry, as Finland was for Estonia or Poland for Latvia, inevitably became the main promoter of Baltic cooperation (Vilpišauskas, 2001, pp. 118119). In these years Lithuania adopted the view which later became to be called "Landsbergis doctrine" (Van Elsuwege, 2008, p. 247). In an attempt to increase its chance to join NATO before other Baltic countries, Lithuania's political elite concentrated on emphasizing the country's historical and modern ties with Poland and other countries of the Visegrád Four. The signing of the free trade agreement between the Baltic countries in 1994 was largely seen as a political gesture, since there was clear rivalry between the countries' economies during this period (Kasekamp, 2010, p. 236). Baltic cooperation then broadly depended on the EU's attitude towards the countries at the time (Vilpišauskas, 2001, p. 118).

In June 1997, the European Commission outlined the action programme Agenda 2000, which laid the foundation for the conclusions of the Luxembourg European Council in December the same year. According to the programme, a decision was made to open accession negotiations with Cyprus, Poland, the Czech Republic, Hungary, Slovenia and Estonia, whereas Latvia and Lithuania together with Slovenia, Bulgaria and Romania were originally left to the "second echelon" (for internal political reasons, Malta had temporarily withdrawn its application). This decision stirred up considerable anger in Latvia and Lithuania, accompanied with accusations of using outdated economic statistics, and resulted in the compilation of new, "more objective" self-analysis reports in 
both countries. Latvia was forced to admit that official statistics indeed failed to represent the gross domestic product of shadow economy and that differences in the official figures and actual economic situation stem from tax frauds and uneven use of accounting standards (Šteinbuka, 1999, p. 51). Latvians, however, had to swallow the bitter pill of the European Commission's main argument that Latvia's economy is only able to produce minimum viable products (Šteinbuka, 1999 , p. 67) and acknowledge their demographic problems, labour quality and training, and several other obstacles in converging with the European Union's economic space even after the country's actual accession (Balabka, 2005). This was also the period of painful reactions of both Estonia's southern neighbours (especially of Latvia) to any statement by Estonian politicians regarding the European Commission's and Council's decision. True, some Estonian politicians (e.g., Toomas Hendrik Ilves, the then Minister of Foreign Affairs, whose disposition towards other Baltic countries was referred to as "allergic" in Lithuania; see Vilpišauskas, 2001, p. 81) indeed tried to emphasize the illusoriness of the "historically imposed" common Baltic identity and stressed that historically Estonia has identified itself usually with the Nordic countries. At this point, again, Lithuanians aptly remembered the "Landsbergis doctrine".

It has been argued that geopolitical motivation and even direct US influence have contributed to Estonia's inclusion in the first round of accession talks (Smith, 2008). During this period, Estonia's economy was presumed to occupy the sixth place among Central and East-European countries (Van Elsuwege, 2008, p. 239) and its problems with Russian minority and the border agreement were far from being resolved. This also explains the attempts to see Estonia's inclusion in accession negotiations through the spectre of geopolitical motivation, which main purpose is to give Russia a clear signal that the Baltic countries are no longer in their zone of influence and is also an effort to avoid the "double shock" for the Baltic population - that is, a situation in which after the decision to include only Poland, the Czech Republic and Hungary in the first round of NATO's enlargement, the EU would also shut the door for the Baltic countries (Smith, 1998).

Regardless of that, two years later in December 1999, the European Council in Helsinki decided that Latvia, Lithuania and four other countries are ready to join accession talks, thus casting aside the "regatta" strategy and adopting the bigbang scenario in EU's Enlargement. Peter Van Elsuwege (2008, p. 289) has seen mostly geopolitical motivation behind this step, because of the onset of Kosovo war in 1999, which brought along increased attention to integrating Bulgaria and Romania. Thus, the objectively better-off countries-Slovakia, Latvia and Lithuania - could no longer be ignored. It is also important to remember that this was the year when the Baltic States were officially named NATO's 
candidate countries. The Göteborg's European Council in June 2001 declared the enlargement process "irreversible" and decided upon the number of seats for the 2004 European Parliament elections at which the Central and East-European newcomers were to participate as members of the EU (Van Elsuwege, 2008, p. 298). Viljar Veebel (2004) believes that there was a 'realistic' possibility at least for Estonia to stay out of the first round of enlargement. This 'Macedonian scenario' as he calls it could mean economic stagnation and Russian-supported unrest in northeastern Estonia (Veebel, 2004, p. 78).

By that time, the EU had, in principle, solved the most burning questions of institutional reform (the principle of allocation of votes in the up to 28-nation union) it had faced in parallel to the enlargement and the reform materialized with the drafting of the Treaty of Nice in December 2000. The resolution to include Latvia and Lithuania, together with Estonia, in the accession negotiations with the EU considerably eased the tensions. It can even be argued that in the course of development (in which joining the $\mathrm{EU}$ is a technical issue rather than a matter of principle), the Republic of Latvia even managed to quantitatively intensify its communication with non-EU members between 1999 and 2004 (Ozolina \& Rostoks, 2006). When speaking about Latvia, political analysts have found it necessary to emphasize the significance of political motivation of being an EU member, especially considering the country's relations with Russia and certain hopes to achieve internal political stability (Šumilo, 1999, pp. 37-39), which, as it is known, has not materialized to a desirable degree.

\section{Accession talks and referendums}

Accession negotiations with Estonia were opened in February 1998, and with Latvia and Lithuania in February 2000. The positions of Latvia and Lithuania, who joined later, in the accession talks were considered more favourable than Estonia's, because by the joining of "late-comers" some chapters of negotiations with Estonia had been already closed and respective agreements concluded (Ragi, 2008, p. 85). In Lithuania, the main debate focused on the reconstruction of Ignalina nuclear power plant, which has the largest Chernobyl type reactor, the issue of Russia's cargo transit to their Kaliningrad enclave through Lithuania and restrictions for foreigners to obtain agricultural land in Lithuania (Maniokas, 2005).

For Estonia and Latvia, the issue of border agreement with Russia became one of the accession requirements (but not part of the very accession talks!). Already before the opening of the negotiations the general view was that border issues 
will not be an obstacle in joining the EU, but they would have to resolve these issues on their own. Estonia subsequently signed the border agreement with Russia as late as in 2005, which Russia refused to ratify, and Latvia reached the border agreement only in 2007. Lithuania had solved somewhat analogous border issues with Poland, resulting from their complicated history, already in 1994 (Van Elsuwege, 2008, p. 84). The main concessions from the part of the Baltic countries was assuming obligations together with other CEECs to enable the 'old' EU Member States (known as EU-15) impose restrictions on free movement of labour, which finally expired on 30 April 2011. In addition, the Baltic countries (again, together with other CEECs) agreed with reduced agricultural subsidies in the framework of CAP.

In the Baltic States the referendums on EU accession agreements were held as follows - on 11 May 2003 in Lithuania, 14 September 2003 in Estonia and 20 September 2003 in Latvia (Auštravičius, 2005, p. 419). Prior to that, among the new democracies in Central and Eastern Europe referendums had been held in Slovenia (23 March 2003) and Hungary (12 April 2003). After the referendum in Lithuania and before those in the other Baltic countries, referendums were held in Slovakia (15-16 May 2003), Poland (8 June 2003) and the Czech Republic (15 June 2003). The schedule followed the model applied before the previous EU Enlargement in 1994, starting with the most euro-optimistic country and holding the last referendums in Estonia and Latvia, where euro-scepticism was the highest. Results were in every way as expected (in Slovenia $89.6 \%$ of voters said 'yes' to EU accession, in Estonia 66.8\%, and in Latvia 67\%), whereas the referendum results in Lithuania (91\% said 'yes') and Slovakia (92.7\% said 'yes') even slightly exceeded the percentages in Slovenia and Hungary, which were the most eurooptimistic at that time. One reason for that is certainly the fact that both Lithuania and Slovakia were among the countries that were left out of the presumed first round of EU Eastern Enlargement on economic and political grounds.

Up to the EU accession, citizen support to the EU passed through more or less similar course of development in all the Baltic States. In the early 1990s, when the European Community / Union was for many a distant dream, the percentage of support to potential accession was relatively high, but in the second half of the 1990s when these prospects started to take shape and specific problems began to emerge, the support clearly diminished. This fluster is most clearly demonstrated by the 1997 Eurobarometer Report, which revealed that had the EU accession referendum been held in November 1996, only 29 per cent of Estonia's population would have voted 'yes'; furthermore, only 17 per cent of the population would have voted 'no', while the total of 52 per cent of the population would have remained indecisive (Kirch \& Talts, 1998, p. 52). In 
Lithuania, the support to the EU dropped to the absolute minimum in December 1999, reaching the mere 29 per cent (Gaidys, 2010, p. 22). On the turn of the century, however, the support to the EU in the Baltic countries started to grow rapidly (in Estonia, by the way, it was largely associated with the winning of the Eurovision Song Contest in 2001). Immediately prior to the referendum, the support to accession in Estonia began to diminish, although not beyond the 60 per cent, while in Lithunia it continued to grow, reaching its peak at 82 per cent immediately after the referendum in January 2004 (Gaidys, 2010, p. 26).

Pre-referendum arguments exploited in the EU support campaign were more or less the same in all the Baltic countries. An analysis of the views of Estonian and Lithuanian euro-sceptics reveals similar arguments (see Raig, 2008, pp. 77-79; Talts, 2000, p. 10; Auštravičius, 2005, p. 420). Already then, Lithuania saw the possibility of the emergence of the negative trend of "brain drain" and all the three Baltic countries agreed on that the local agricultural sector would suffer. In Latvia the total of 60 per cent of those who voted 'no' at the referendum claimed that their main reason for voting against was concern about the country's agriculture (Auers, 2007, p. 141). Some arguments, put forward in 1997-1999 by Estonian euro-sceptics, such as the potential growth in unemployment rate, were gradually rejected (Talts, 2002, p. 11). Employment rate showed slight upward movement directly before the EU accession and a rather rapid decrease after the accession (Estonia's unemployment rate in 2000 was 13.7\%, in 2004 it was $9.4 \%$ and in $2007-4.6 \%$; during the same years the percentages in Latvia were $13.7 \%, 11.2 \%$ and $6.5 \%$, respectively, and in Lithuania $16.4 \%, 11.3 \%$ and $3.8 \%$, respectively; see Eurostat, 2013) and the unemployment rate skyrocketed again at the onset of the global economic crisis in 2009.

\section{Public opinion development trends in the post-referendum period}

In the period following the EU accession referendum, the population support to EU membership in Estonia has continued to increase (Fig. 1), whereas in Lithuania, for example, it has shown a downward tendency (Fig. 2). Among the possible reasons for that are differences in cultural mentality. Pre-referendum debates in Estonia entailed various claims and threats of arguably negative tendencies that would accompany accession, but many of these (e.g., deep economic depression, abrupt rise in taxes, immigration from Southern Europe, etc.) never materialized. 
Figure 1. The Dynamics of EU support in Estonia 2004-2008

\section{Opinion of Estonian Voters on EU Membership 2004-2008}

support + rather support $\square$ oppose + rather not support $\square$ no opinion

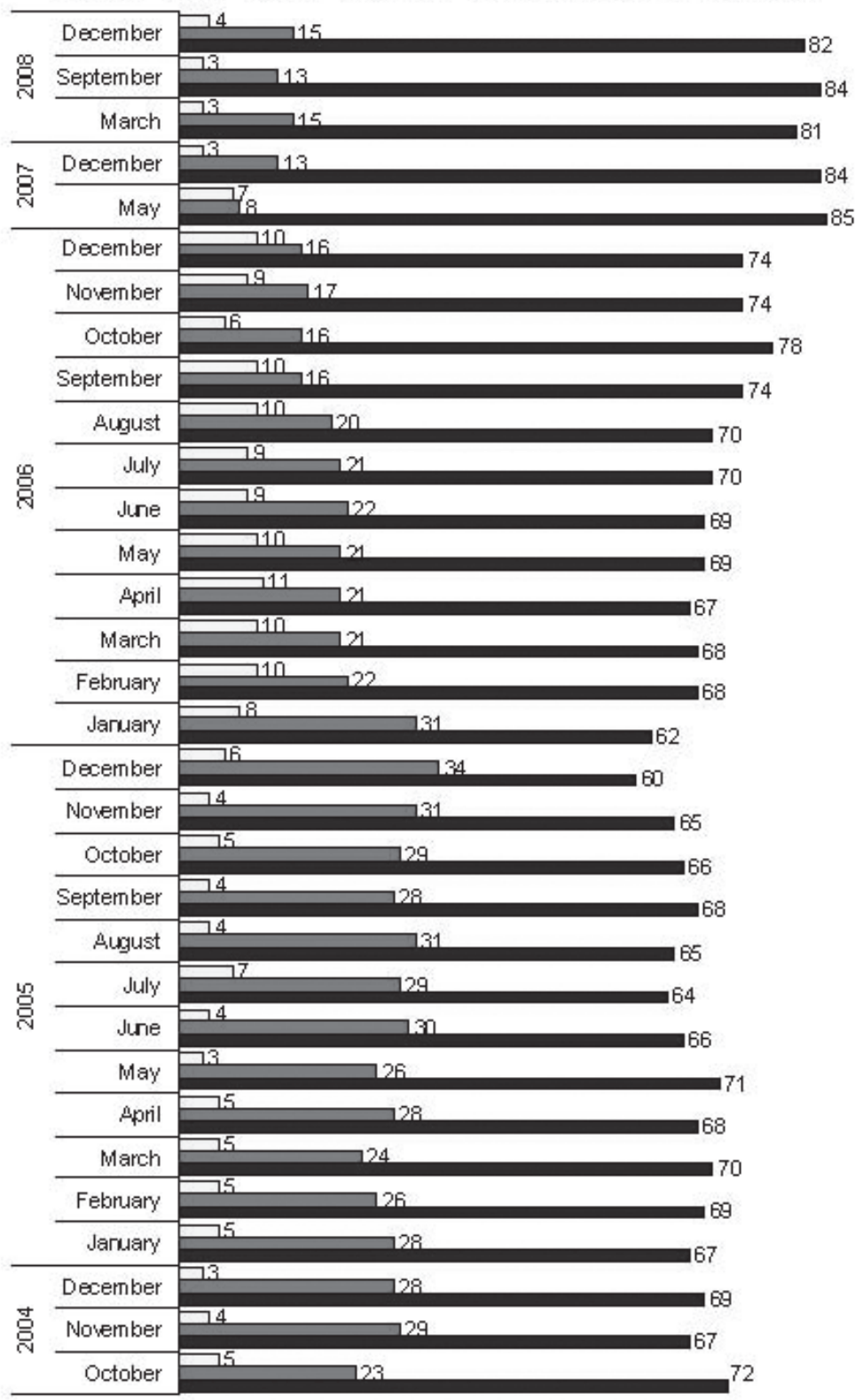

Source: TNS EMOR 
On the contrary, the period to come was characterized by the fastest economic growth in Estonia's recent history. Estonia has witnessed a slight decline in public support to the EU only in the most recent years. In November 2012, the total of 74 per cent of the respondents supported Estonia's membership in the EU, while 22 per cent were against (Faktum \& Ariko, 2012). Such decline in support is comprehensible in circumstances of Estonian public and media wondering "whether they really have any active power to influence the European Financial Mechanism build-up and energy relations between the European Union and Russia (Veebel \& Loik, 2012, p. 182).

Lithuanians, on the other hand, got carried away with the general pro-European euphoria, and were keen to put themselves back on the map after the 1997 "humiliation", in order to stay in the game, but in the following years these heightened expectations turned into certain disappointment, which among other things has been indicated by the rapidly growing emigration wave from Lithuania. Analogous processes in Lithuania's public opinion had taken place already during the restoration of independence and directly after that, when heightened expectations and hindering reforms inevitably led to later disillusionment (cf. Gaidys \& Tureikytè, 1994; Gaidys, 1998).

Lithuanian sociologist Vladas Gaidys in his comparative research of the attitudes of the Baltic nations towards the past, present and anticipated future in the 1990s has argued that evaluation of the Soviet past was counteractive to the evaluation of the present, and that while in the 1990s Lithuanians' assessment of their economic present became more pessimistic, the tendency in Estonia was quite the opposite (Gaidys, 1998). Gaidys explained this through differences in the nations' cultural background, claiming that as majority Catholics, Lithuanians tend to be more fatalistic, conservative and hold on to a more holistic world view which is based on emotions rather than reasoning (Gaidys, 1998, pp. 6566). Lithuanians' general disposition to emotionality is, among other things, illustrated by the fact that after the privatization of Lithuanian Telecom in 1998 and the following doubling of call tariffs, Lithuanians came to the streets and the incident (together with the confusion surrounding the Ignalina power plant) was strongly associated with a sudden drop in support to the EU at the end of the past century (Gaidys, 2010, p. 22). In 2005 and 2006, Lithuanians' support to the EU was still high but then began to fall. With the problems with Russian oil and gas supplies and EU's inadequate response to these problems in 2007, the popularity of the EU in Lithuania decreased (Čičinskas, 2007). Be that as it may, by September 2010 Lithuania's support to the EU had fallen to 62 per cent, as shown in Figure 2 (Gaidys, 2012, p. 72). 
Figure 2. Attitudes towards Lithuania's membership in the EU: 2000-2011

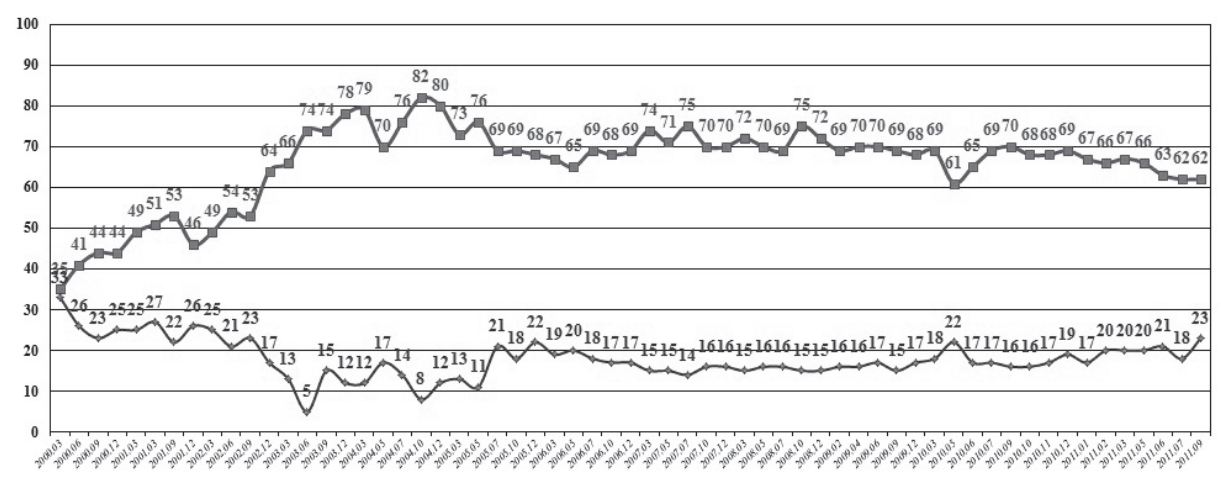

$\rightarrow$-in favour $\rightarrow$ against

One of the things that may have contributed to the following disillusionment was perhaps the fact that while EU membership has certainly helped to improve their position in communications with Russia, the situation is far from satisfactory. The once highly anticipated breakthrough has not been achieved. Furthermore, Putin's Russia has made any effort to make the Baltic countries seem as European Union's "problematic newcomers" (Kasekamp, 2011, p. 244) and this did not change even during Dmitri Medvedev's presidency, regardless of the cautious optimism in this regard (Muiznieks, 2008). The main reasons for that lie in the poor coordination of EU's own foreign politics. Of the three Baltic countries, mostly Estonia and Lithuania have taken minimal steps towards reducing Russia's economic influence. For example, in 2006 Lithuania sold Mažeikiai's oil refinery to a Polish company instead of Russian investors (Kasekamp, 2011, p. 245). In Lithuania, the problems surrounding the decommissioning of the Ignalina nuclear power plant, which costs have exceeded all past estimates and is still unresolved, have definitely fuelled euro-scepticism (Vilpišauskas, 2012). One of the factors influencing EU's popularity in Latvia may be the issue of European Union's imposing sanctions against Belarus, Latvia's important trade partner (Muravska, 2012). 


\section{Simultaneous economic developments}

During the disintegration of the Soviet Union, the economy of the Baltic countries was, naturally, in a disastrous state. The entire economy had been built upon Soviet internal market, which meant that some sectors (e.g., agricultural meat industry) were irrationally overdeveloped, while others were partly or completely undeveloped. Economic slowdown in the last decades of the Soviet Union encompassed the entire area and this necessitated the fast implementation of property reform and the restitution of property nationalized during the Soviet occupation, a process which had enormous political and legal significance but had only subtle positive influences on the economic situation. The aim of the property reform was the justified compensation for former injustice and had roots in the ideology of reinstating nationhood, but in many cases (for example, in agriculture) it proved to obstruct rather than encourage economic activities. Restoration, restructuration and reorientation of economy to new markets was unthinkable without an inflow of foreign investments.

In the privatization process, Estonia more than the other Baltic countries chose the strategy to favour foreign investments. Lithuania at the same time attempted to impose certain restrictions, the most important of which was the prohibition of selling land to foreigners, which caused serious tension in Lithuanian-EU relations in the second half of the 1990s. Paradoxically, the local Estonian noncorporate owners proved to be more successful than foreign investors (Terk \& Pihlak, 1996). But already since the second half of the 1990s, many enterprises which started out as Estonian businesses have been incorporated in foreign corporations. All in all, the Estonian auction-based privatization model, which has certainly favoured foreign investment, has moved a relatively large portion of national assets to foreign ownership, but at the same time it has helped to avoid local corruption and the emergence of oligarchs in the region (Lauristin, 2008, p. 193). The selling of the few left domestic leader companies to foreign (mostly Nordic) investors was propelled by the onset of the economic crisis in 2008, which weakened the already commenced invasion of Estonian companies to "southern"- that is Latvian and Lithuanian-markets (Terk, 2011, p. 174).

To restore economic activity, the Baltic countries had to choose between two rather conflicting courses of development (or "extremes") - the liberal market economy ("the Anglo-American model") and the so-called coordinated market economy ("the German model"). Most economists agree that of all the new Central and East-European democracies, Estonia has chosen the most liberal course, while Slovenia most clearly represents the so-called coordinated market 
economy among the transition countries (Buchen, 2007; Feldmann, 2006; Frane, Primož \& Tomšič, 2009). The development course chosen by Latvia and Lithuania approaches Estonia on the liberality-sociality scale, but this has not been the case during the entire period since the restoration of independence. After regaining independence, Lithuania, then under the rule of the Democratic Labour Party, tried to force through the course of "sociality" (which entailed subsidies to the agricultural sector, certain lenience in old-age pension criteria, voucher-based privatization, etc.), but their strategy proved counterproductive and instead of the hoped "social benefit" it brought along disappointment in the same layers of society at whom such "socially-minded course of politics" was targeted (Lauristin, 2011b, p. 195).

Therefore, in recent years Lithuania has made efforts to approach the "Estonian model" (Lauristin, 2011b, p. 192). During the last economic crisis in particular, Lithuania's government under Andrius Kubilius has implemented harsh public sector cutbacks, which, however, have not resulted in other steps (Maniokas, 2009). Also, Latvia, which has a slightly different economic structure because of the transit sector, which in a way resembles the casino-oriented and oligarchic structure of Russian economy, has tried to execute the most coordinated market economy policies of the three Baltic countries (Norkus, 2011, p. 31).

Despite the differences, the three Baltic countries could still be regarded as "faithful followers of the Washington Consensus" of "the ideas of liberal economy", developed by the IMF and the World Bank (Terk \& Reid, 2011, p. 32 ) and have introduced in the discourse the so-called Baltic neoliberal model of capitalism (Norkus, 2011, p. 25). Thus, the differences between the Baltic countries become noticeable only at closer look, but on the broader scale of world economy they continue to represent economies of rather similar development and structure.

Structural changes in the Baltic economies have taken place rather extensively and extremely rapidly in the years of independence. Estonia's employment rate in the primary sector (agriculture, fishing, forestry), for example, dropped from nearly 10 per cent by nearly half in less than eight years, while in the developed the Nordic countries, it had taken 13 to 16 years (Eamets, 2011, p. 77). Referring to the relatively high percentage of primary sector, Ramūnas Vilpišaukas has speculated that for EU's reform of the Common Agricultural Policy (CAP), Estonia should choose Germany, Sweden, the UK and the Netherlands as its coalition partners, whereas Latvia's and Lithuania's positions would resemble rather that of France, Italy, Poland and Romania than countries with economies dominated by agricultural sectors and which by nature oppose the radical 
reforming of CAP (Vilpišauskas 2005, p. 478). Hungarian economist András Inotai (2008) has also expressed similar views. Daunis Auers, who has analyzed the situation of Latvian agricultural policy, is convinced that while the CAP reform would be detrimental to Latvia in the short run, in a longer perspective the country would have to support the liberalization of EU's agricultural policy (Auers, 2007, pp. 154-155).

In the preuntries had reached the remarkable 10 per cent and even above (Lauristin, 2011a, p. 11). In Estonia, it has been emphasized, the "new money" that flooded the country was not used for the needed future-oriented structural investments into branches of industry with export capability or similar areas, but to encourage internal consumption and real estate development (Norkus, 2011, p. 26). Salaries surged upwards faster than labour productivity, which, in turn, decreased the Baltic countries' competitiveness and accelerated the growth of private sector loans as well as consumption loans to private individuals, because the people were not willing to downshift their standard of living. The current account deficit of the Baltic countries rose considerably also before 2004, when direct foreign investments in the region supported primarily real economy (Annenkov \& Berglöf, 2011). Likewise, the other Baltic countries neglected making the necessary structural changes in their economy. Irina Čurkina, who analyzed the situation in Latvian economy in 2005, also came to the conclusion that several developments in Latvian economy at the time were similar to those occurring before the 1997-1998 East-Asian crisis (Čurkina, 2005, pp. 80-82, 92). The Baltic States became increasingly dependent on the banks of other countries and the share of private sector loans in foreign currency (euros) grew.

The depth of the crisis became particularly evident in unemployment statistics. When in 2007 the unemployment rate in Estonia was 4.6 per cent, by 2009 it had grown to 13.8 per cent and by 2010 to 16.9 per cent. Latvian unemployment rate of 6.5 percent in 2007 grew - and post-accession period, the economies of all the Baltic countries turned to growth, and the future seemed cloudless. In addition to growth in export to the EU countries, the export to the so-called third countries also increased between 2004 and 2007, contrary to eurosceptics' claims (Inotai, 2008). Without exaggeration it may be agreed that EU accessions, the accompanying jumpstart of direct and portfolio investments and the unlimited influx of "free" loans was at least one contributing factor to the unprecedented economic boost in the area, and, in a sense, prepared the ground for the particularly devastating shock in the 2008 economic crisis. From 2005 to 2007 the economic growth in all the Baltic coto 18.2 percent by 2009 , reaching 19.8 percent in 2010. In Lithuania the official unemployment rate in 2007 was only 3.8 per cent, rising to 13.6 per cent in 2009 and 18 per cent 
in 2010 (see Eurostat, 2013). Between 2007 and 2009 Latvia experienced the record-breaking 27 per cent economic decline and the actual unemployment rate in 2010 was at least 30 per cent, taking into account people forced into part-time work and those who had given up looking (Moulds, 2012). It has to be remembered, though, that these figures were obtained in a situation where the official statistics did not adequately reflect the unemployment rate and the mass emigration which potentially contributes to the locally unemployed had been a reality for some time now.

In the light of the macro-economical statistics, the Baltic countries have begun to emerge from the crisis since 2011, but the question about the lesson they learned is still largely unresolved. During 2008 to 2010, the economic recession hit the Baltic States the hardest of all the EU Member States, but fortunately the applied deflation policy has brought about a slight rise, as shown about Estonia in Figure 3.

Figure 3. Development dynamics in Estonian economy during 2000-2011

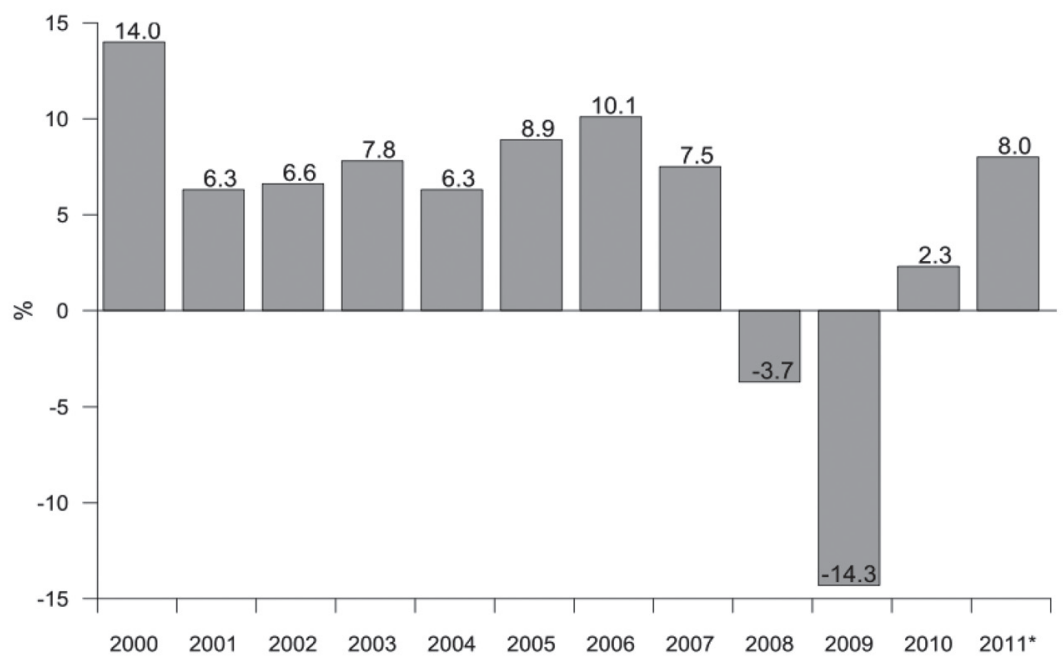

Source: Data of Statistics Estonia

A negative aspect of reforms in the Baltic region has been the relatively high corruption level in the countries. According to the Corruption Perceptions Index, composed by Transparency International in 2001, Estonia was ranked the $29^{\text {th }}$, Lithuania the $50^{\text {th }}$ and Latvia the $61^{\text {st }}$ among the total of 183 countries $(C P I, 2011)$. This is definitely a problem, especially since 75 per cent of Lithuanians, for example, 
believe that bribery helps to solve problems and 65 per cent would be willing to give bribes (Urbonas, 2009, p. 68), which is evidence of corrupting turning into a kind of "culture" in Lithuania. Latvian oligarchs' political interventions have been also seen as a far more serious problem than simple bribery and nepotism (Lejinš, 2007). Corruption is certainly one of the reasons why people feel alienated from politics and politicians, especially in Latvia and Lithuania. Paradoxically, the local media, which so far enjoys a rather high level of confidence compared to other institutions, cultivates distrust by exploiting this topic. Thus Latvia and Lithuania continue to find themselves in a double bind of political distrust, voting at each elections for new populist parties only to become disappointed in them once again (Pettai, Auers \& Ramonaitè, 2011, p. 157).

\section{The social cost of Baltic economic reforms}

The rapid changes in economy, mainly caused by the implementation of the model of liberal capitalism, have revealed a clearly negative influence, having brought along abrupt social stratification, the unlimited impoverishment for some levels of society, drop in birth rate, growth in manifestations of antisocial behaviour (e.g., alcoholism) and the general alienation and disappointment in one's country and leaving abroad in search for better economic opportunities. The cost of economic reforms carried out in the Baltic countries is illustratively reflected even by the Human Development Index (HDI) of these countries, measured according to the UN methods. The index is calculated on the basis of (a) gross national income per capita indicating the country's economic level, (b) mean expected years of schooling characterizing the level of education, and (c) life expectancy at birth as an index of the quality of life. Estonia's highest rank in HDI of the Baltic countries is based on the relatively good economic and its excellent education index, although the relatively low average life expectancy is systematically dragging it down (Vihalemm, 2011, p. 13). This is evidence of the rather modest level of health care in Estonia, but even more so of the increasing carelessness of the population toward their health. Since 2010, the UN HDI has taken into consideration the fact that health, education and income are often highly uneven within the country. In Estonia, the inequality-adjusted index (IHDI) is 9.8 per cent lower than the general index, while in Latvia and Lithuania the IHDI is already 10.8 to 11.5 per cent (Vihalemm, 2011, p. 16).

It inevitably concludes that Estonia has achieved its economic success largely at the expense of human capital deficit and by constant postponing of solving 
the issues important for human development (Lauristin, 2008, p. 197). Even the traditional unemployment insurance system was implemented in Estonia as late as in 2002, a decade after the reforms were introduced (Eamets, 2011, p. 78). Unfortunately, the same can be concluded about the other Baltic countries, where the practise of "foot voting" has been even more intense. In the first year and a half of Latvian accession to the EU, nearly 100,000 Latvians from mostly rural areas emigrated from the country (at first "temporarily" to Ireland and the United Kingdom) in search of employment (Auers, 2007, p. 147). Even though most of them later repatriated, the migration rate clearly skewed toward the negative even before the economic crisis. It is worth noting that actual migration is under-registered in official statistics in the range of 30 to 60 per cent (Eamets, 2011, p. 81). Between 2004 and 2010 at lely oppose to cultures, say, in Southern Europe with low rationality and high leveast 125,000 people have left Latvia and during the same period at least 259,000 people have emigrated from Lithuania (Kirch, 2013). Vladas Gaidys (2010, p. 29), relying on the somewhat indirect data obtained through sociological research, estimates that the total number of Lithuanians who have left their country is 300,000 . By today, the number has reportedly exceeded 400,000 (Kirch, 2013).

Especially in terms of Estonia, researchers have noticed a certain unique psychological tendency of the population to paradoxically support the government who, while favouring liberal policy, continues to make cutbacks, and the willingness to make allowances in the situation. The Finnish political scientist Henri Vogt (2011) has tried to explain the phenomenon through the concept of "national liberalism". The majority of Estonian population, Estonian society, have accepted the social gaps and contrasts and have begun to view these as 'natural' (or even inevitable) (Lauristin, 2011a, p. 11). This might explain the paradox why Estonians have continued to re-elect political parties who favour liberal policy through the $21^{\text {st }}$ century.

According to the result of analysis based on the methodology of Ronald Inglehart's World Values Survey, the Baltic countries, as an entity, have been viewed as cultures of high rationality and clearly focused on material wellbeing (Lauristin, 2011b, p. 196) and as such they strongl of expression. The Baltic countries' common feature with the Nordic countries and Germany is of course high rationality, but the soft values characteristic of these welfare societies are still quite unfamiliar to people in the Baltics. The recent economic crisis seems to have widened the gap even more. 


\section{Conclusions}

This overview attempted to map the process that could be defined as "the Baltic states' convergence to the European Union". While the topics have not been fully resolved and are thus worth exploring, the general tendencies can be outlined in the master narrative of the transition processes in the Baltic countries:

The Baltic countries have always needed the EU more than the EU has needed them. The governments of the Baltic countries have thus adopted a relatively compliant attitude towards the EU, except in issues of citizenship and language policy and relations with Russia, where some compromises have been made but first securing one's positions. The aspiration to present oneself as EU's Wunderkind is quite common in Estonia and Latvia (see Lejinš, 2007). Likewise, Lithuania has tried to present itself as an exemplary member of the European Union, being among the first countries to ratify the Constitutional Treaty in November 2004 (Čičinskas, 2007). This was regarded as the first step pushing Lithuania on the path of growing euro-scepticism, after which preferring a more pro-active "politics based on national interests" (for example, by President Dalia Grybauskaite) has enjoyed certain growth in popularity (see Noreika, 2013).

Being an EU member has both economic and political advantages for the Baltic countries (especially in their relations with Russia). In the 2008-2010 economic crisis emerged the question whether the Baltic countries as a kind of testbed for economic-political measures and the experience gained here could be used as a model for other EU Member States, of course assuming there is enough political and social willingness and certain sense of sacrifice. Especially the latter seems to be somewhat lacking.

Until the actual accession to the EU the public opinion polls followed more or less the same course of development. The carefree euro-optimist of the early 1990s (the expectations to become accepted "to the club of developed countries") was followed by decline in support to the EU before and after the turn of the century, which was largely connected with the emergence of certain questions in what was actually the looming EU debate. Immediately before the referendum, the support to the EU started to show upward tendencies, resulting in the victory of 'yes' voters at the 2003 referendums. Between 2004 and 2013, in the years of actual EU membership, the support to the Union has slowly but steadily grown, whereas the Latvian citizens has retained their euro-scepticism and in Latvia the previously rather euro-optimistic figures have slowly but surely started to fall. However, as a result of the economic crisis in 2008-2011 the support to the 
EU in Estonia has shown a slight decline, which occurred with short delay and became evident in 2012 (Faktum \& Ariko, 2012).

Except for the 1990s, the economic and social developments of Estonia, Latvia and Lithuania in the EU context have been somewhat surprisingly synchronized ever since the pre-accession period. The differences (although quite noticeable in some areas) have been quantitative rather than qualitative. In Latvia the economic growth was the most rapid, rise in unemployment rate the largest, and the exhaustion of state reserves the most devastating, and this lead to the country's appeal to IMF for help. IMF's conditions more or less coincided with the policies that the governments of Estonia and Lithuania had already voluntarily adopted. Emigration is still the burning issue in Lithuania and Latvia, and the loss of young working-age population is no longer a secondary problem for Estonia either. It could be claimed that the onset of the global economic crisis in 2008 and the subsequent implementation of basically analogous economic policies has brought the countries closer to each other.

The differences between Estonia and Lithuania mostly derive from the somewhat different culture, mentality, expectations and subjective worldview of these nations, which result in different evaluations of similar developments. Objectively, their economic and social developments have been surprisingly similar throughout the past ten years-in the longer run it might cause major changes in mentality in Lithuania, bringing the Lithuanians' mindset closer to the other Baltic nations. The developments of the most recent years, however, seem to suggest Latvia's deviation from the course of development of the other Baltic countries, but whether this will become a reality, will be for the future to decide.

Mait Talts has studied at the University of Tartu, graduated from the Tallinn University as an information specialist. He has a working experience from the Institute of Experimental Biology of Estonian Academy of Sciences, Estonian Childrens' Literature Centre, Estonian State Archives, Institute of International and Social Studies of Tallinn University, and International University Audentes. He has taught several courses at Viljandi Culture Academy, Tallinn Pedagogical Seminar and Tallinn University of Technology. Currently he is a PhD student at the Department of International Relations of Tallinn University of Technology and the research secretary of the same department. 


\section{References}

Adam, F. ; Primož, K. \& Tomšič, M. (2009), 'Varieties of capitalism in Eastern Europe (with special emphasis on Estonia and Slovenia),' Communist and PostCommunist Studies, vol. 42, no. 1 (March), pp. 65-81. http://dx.doi.org/10.1016/j.postcomstud.2009.02.005

Annenkov, A. \& Berglöf, E. (2011), 'Baltic lessons for Europe's future economic governance,' Europe's World, no. 17 (Spring 2011), pp. 70-77.

Auers, D. (2007), 'Friend or foe? Latvia and Europe's Common Agricultural Policy,' in Ž. Ozolina (ed.) Latvia's View of the Future of the European Union, Riga: Zinātne, pp. 141-159.

Auštravičius, P. (2005), 'Referendum on membership of the European Union and organisation of vthe information campaign,' in K. Maniokas, R. Vilpišaukas \& D. Žeruolis (eds.) Lithuania's Road to the European Union: Unification of Europe and Lithuania's EU Accession Negotiations, Vilnius: Eugrimas, pp. 411- 436.

Balabka, N. (2005), 'Conditions of development of business in Latvia,' Humanities and Social Sciences. Latvia, no. 1 (45), pp. 130-148.

Buchen, C. (2007), 'Estonia and Slovenia as antipodes,' in D. Lane \& M. Myant (eds.) Varieties of Capitalism in Post-Communist Countries, Houndsmill: Palgrave, 65-89.

Čičinskas, J. (2007), 'Lithuanians learn hard lessons about dealing with the EU,' Europe's World, no. 6 (Summer 2007), pp. 157-158.

CPI (2011), Corruption Perceptions Index, Transparency International. Retrieved from http://www.transparency.org/cpi2011/results [accessed 15 April 2013]

Čurkina, I. (2005), 'The history of economic crises in the world's developing countries and the possibility of crisis in Latvia,' Humanities and Social Sciences. Latvia, no. 1 (45), pp. 74-94.

Eamets, R. (2011), 'Tööturg, tööturu paindlikkus ja majanduskriis Balti riikides,' [Labour market, its flexibility and the economic crisis in the Baltic States] in Eesti Inimarengu Aruanne 2010 / 2011. Inimarengu Balti rajad: Muutuste kaks aastakümmet, Tallinn: Eesti Koostöö Kogu, pp. 75-82.

EHDR (2011), Eesti Inimarengu Aruanne 2010/2011: Inimarengu Balti rajad / Estonian Human Development Report 2010/2011 [in Estonian], Tallinn: Eesti Koostöökogu.

Eurostat (2013), 'Unemployment rate by sex and age groups: annual average, \%,' Eurostat. Retrieved from http://appsso.eurostat.ec.europa.eu/nui/show. do?dataset=une_rt_a\&lang=en [accessed 9 May 2013]

Faktum \& Ariko (2012), Arvamusuuring "Elanikkonna toetus Euroopa Liidule ja eurole”, Tallinn: Faktum \& Ariko. Retrieved from http://valitsus.ee/UserFiles/ 
valitsus/et/riigikantselei/uldinfo/dokumendiregister/Uuringud/Elanikkonna $\% 20$ toetus\%20Euroopa\%20Liidule\%20ja\%20eurole_aruanne.pdf [accessed 15 April 2013]

Feldmann, M. (2006), 'Emerging varieties of capitalism in transition countries: Industrial relations and wage bargaining in Estonia and Slovenia,' Comparative Political Studies, vol. 39, no. 7, pp. 829-854.

http://dx.doi.org/10.1177/0010414006288261

Gaidys, V. (1998), 'Attitudes towards the Economic System in the Baltic States: Past, Present, Future,' in K. Junefeldt, M. Peterson \& L. Martin (eds.) Cultural Encounters in East Central Europe, Stockholm: Swedish Council for Planning and Coordination of Research, pp. 61-73.

(2010), 'Lithuania in the European Union: Public Opinion Research Results,' Proceedings of the Institute for European Studies, Journal of Tallinn University of Technology, no. 7, pp. 21-38.

— (2012), 'Ekonominių nestabilumų atspindys visuomenès sąmonèje,' in Lietuvos socialinè raida. Lietuvos socialine raida ekonomikos nuosmukio sąlygomis, no. 1, pp. 54-75.

Gaidys, V. \& Tureikytė, D. (1994), Nuomones 1989-1994, Vilnius: Filosofijos, Sociologijos ir Teises Institutas, Viešosios Nuomones Tyrimu Centras.

Grabbe, H. \& Hughes, K. (2000), Enlarging the EU Eastwards, London \& New York: Royal Institute of International Affairs.

Inotai, A. (2008), 'Mixed thoughts of an EU newcomer,' Europe's World, no. 9 (Summer 2008). Retrieved from http://www.europesworld.org/NewFrancais/ Accueil/Article/tabid/190/ArticleType/artileview/ArticleID/20337/language/enUS/Default.aspx [accessed 15 April 2013]

Kasekamp, A. (2010), Balti riikide ajalugu [History of the Baltic States], Tallinn: Varrak.

Katus, K.; Puur, A. \& Sakkeus , L. (2002), 'Immigrant population in Estonia,' in W. Haug, P. Compton \& Y. Courbage (eds.) Demographic characteristics of immigrant population, Strasbourg: Council of Europe Publishing, pp. 131-192.

Kirch, A. (2013), 'Baltic States, migration, $20^{\text {th }}$ century to the present,' in Encyclopedia of Global Human Migration, Oxford: Wiley-Blackwell Publishing.

Lauristin, M. (2011a), 'Inimareng siirdeajal: Balti riikide ees seisvad väljakutsed, [Human development in times of transition: the challenges of the Baltic countries]' in Eesti Inimarengu Aruanne 2010 / 2011. Inimarengu Balti rajad: Muutuste kaks aastakümmet, Tallinn: Eesti Koostöö Kogu, pp. 10-12.

(2011b), 'Kokkuvõtteks. Milline võiks olla Balti tee XXI sajandil? [Conclusion: what could be the Baltic way in the $21^{\text {st }}$ century?]' in Eesti Inimarengu Aruanne 2010 / 2011. Inimarengu Balti rajad: Muutuste kaks aastakümmet, Tallinn: Eesti Koostöö Kogu, pp. 192-198. 
Lejinš, A. (2007), 'EU's model member Latvia has still to rout its Oligarchs,' Europe's World, no. 5 (Spring 2007), pp. 157-159.

Maniokas, K. (2005), 'Introduction,' in K. Maniokas, R. Vilpišaukas \& D. Žeruolis (eds.) Lithuania's Road to the European Union: Unification of Europe and Lithuania's EU Accession Negotiations, Vilnius: Eugrimas, pp. 9-15.

— (2009), 'Lithuania's “austerity crusade" threatened by deepening recession,' Europe's World, no. 12 (Summer 2009), pp. 164-165.

Meri, L. (1996), 'Meie piir on Euroopa väärtuste piir,' [Our border is the border of European values] in L. Meri Presidendikõned [Presidential Speeches], Tartu: Ilmamaa, 325-331.

Moulds, J. (2012), 'Estonia and Latvia: Europe's champions of austerity?' The Guardian, 8 June 2012.

Muiznieks, N. (2008), 'Latvia still among the flies in the EU-Russia ointment,' Europe's World, no. 12 (Autumn 2008), pp. 194-195.

Muravska, T. (2012), 'Latvia counts the cost of tightened EU sanctions against Belarus,' Europe's World, no. 21 (Summer 2012), pp. 134-135.

Noreika, M. (2013), 'Grybauskaitė: ES turi priemonių, bet neturi valios,'[Grybauskaitė: The EU has the means but no will] Verslo Žinios, 1 February 2013.

Norkus, Z. (2011), 'Võrdlev pilguheit Eesti, Läti ja Leedu postkommunistlikule arengule [Comparative view of the post-communist development of Estonia, Latvia and Lithuania],' in Eesti Inimarengu Aruanne 2010 / 2011. Inimarengu Balti rajad: Muutuste kaks aastakümmet, Tallinn: Eesti Koostöö Kogu, pp. 22-31.

Ozolina, Ž. \& Rostoks, T. (2006), 'Eastern and Western Latvian foreign policy after 1999: a comparative quantitative approach,' in Expanding Borders: Communities and Identities, Proceedings of International Conference. Riga, November 9 -12, 2005. Riga: University of Latvia, pp. 341-361.

Päevaleht (1991), 'Landsbergis pakub majandusühendust, Müllerson eitab blokipoliitikat,' [Landsbergis proposes economic union, Müllerson denies bloc politics] Päevaleht, 21 September 1991, p. 1.

Pettai, V.; Auers, D. \& Ramonaite, A. (2011), 'Poliitiline areng,' [Political development] in Eesti Inimarengu Aruanne 2010 / 2011. Inimarengu Balti rajad: Muutuste kaks aastakümmet, Tallinn: Eesti Koostöö Kogu, pp. 144-164.

Raig, I. (2008), Eesti tee Euroopa Liitu. Unistus paremast Euroopast [Estonia on the road to the EU: A dream of Europe more beautiful], Tallinn: Rahvusvaheline Ülikool Audentes.

Rimšēvičs, I. (2011), 'Commentary,' Europe’s World, no. 17 (Spring 2011), pp. 71-77.

Ruutsoo, R.; Kirch, A; Tuisk, T. \& Talts, M. (1998), 'Estonia at Europe's threshold,' Revue Baltique, no. 11, pp. 11-19.

Smith, D. J.; Pabriks, A.; Purs, A. \& Lane, T. (2002), The Baltic States: Estonia, Latvia and Lithuania, London \& New York: Routledge. 
Smith, K. E. (1998), 'The use of political conditionality in the EU's relations with third countries: how effective?' European Foreign Affairs Review, vol. 3, no. 2, pp. 253- 274 .

Šumilo, E. (1999), 'Latvia's interests in joining the EU,' in B. Lesser (ed.) Latvia and the European Union, Halifax (Canada): Baltic Economic Management Programme, pp. $35-47$.

Šteinbuka, I. (1999), 'Latvia on the way to the EU: economic policy convergence,' in B. Lesser (ed.) Latvia and the European Union, Halifax (Canada): Baltic Economic Management Programme, pp. 49-71.

Talts, M. (2002), 'Euroopa Liidu teemalise debati areng ja probleemid Eesti ajakirjanduses [The development of EU debate and issues in the Estonian press], Tartu: Tartu Ülikooli Tartu Ülikooli Euroopa Kolledž.

— (2004), 'Paradigmamuutuse lävel : Mõtted seoses mitme referendumiaastal ilmunud raamatuga [A change in paradigm: Reflections on works published in referendum years],' in A. Kirch (ed.) Eesti Euroopa teel: arenev majanduskeskkond ja uuenevad identiteedid, Tallinn: Teaduste Akadeemia Kirjastus, pp. 118-128. (2007), 'Estonia's show-down has done wonders for the EU's popularity,' Europe's World, no. 7 (Autumn), pp. 177-178.

Talts, M. \& Kirch, A. (1998), 'Eesti ja teiste Baltimaade eurointegratsiooni valmidusest: võrdlevalt Eurobarometer 1997 alusel [Euro-integration preparation of Estonia and the Baltic States: a comparison based on Eurobarometer 1997],' in R. Ruutsoo \& A. Kirch (ed.) Eesti Euroopa Liidu lävepakul, Tallinn: Eesti Teaduste Akadeemia kirjastus, pp. 46-56.

Terk, E. (2011), 'Eesti, Läti ja Leedu vaheliste majandussuhete dünaamika [Dynamics in economic relations between Estonia, Latvia and Lithuania],'in Eesti Inimarengu Aruanne 2010 / 2011. Inimarengu Balti rajad: Muutuste kaks aastakümmet, Tallinn: Eesti Koostöö Kogu, pp. 173-177.

Terk, E. \& Pihlak, Ü. (1996), 'Privatised enterprises: What has become of them?' The Baltic Review, no. 10, pp. 23-24

Terk, E. \& Reid, A. (2011), 'Tee riigiettevõtetelt innovatsioonipõhisele eraettevõtlusele [Shift from state enterprises to innovation-based private enterprise],'in Eesti Inimarengu Aruanne 2010 / 2011. Inimarengu Balti rajad: Muutuste kaks aastakümmet, Tallinn: Eesti Koostöö Kogu, pp. 31-40.

Urbonas, R. (2009), 'Corruption in Lithuania,' Connections: The Quarterly Journal, vol. 9, no. 1 (Winter 2009), pp. 67-92.

Van Elsuwege, P. (2008), From Soviet Republics to EU Member States. A Legal and Political Assessment of the Baltic States'Accession to the EU, LeidenBoston: Martinus Nijhoff. http://dx.doi.org/10.1163/ej.9789004169456.i-585

Veebel, V. (2004), 'Conditionality and dependence as key elements in simultaneous democratization and crises prevention,' in A. Kasekamp (ed.) The 
Estonian Foreign Policy Yearbook 2004, Tallinn: Estonian Foreign Policy Institute \& Varrak, pp. 63-84.

Veebel, V. \& Loik, R. (2012), 'Estonia,' in D. Ó Beacháin, V. Sheridan, S. Stan (eds.) Life in Post-Communist Eastern Europe after EU Membership: Happy ever after? Abingdon \& New York: Routledge, Taylor \& Francis Group, pp. 163-184.

Vihalemm, P. (2011), 'Globaalne inimarengu indeks: Läänemere maade sarnased ja erinevad arengujooned [Global Human Development Index: Differences and similarities in the development of the Baltic countries],'in Eesti Inimarengu Aruanne 2010 / 2011. Inimarengu Balti rajad: Muutuste kaks aastakümmet, Tallinn: Eesti Koostöö Kogu, pp. 12-18.

Vilpišaukas, R. (2001), Integracija Europoje: Baltijos šalys ir Europos Sajunga, Vilnius: Arlila.

(2005), 'Lithuania in European Union politics. National interests and intergovernmental coalitions,' in K. Maniokas, R. Vilpišaukas \& D. Žeruolis (eds). Lithuania's Road to the European Union: Unification of Europe and Lithuania's EU Accession Negotiations, Vilnius: Eugrimas, pp. 46-492.

- (2012), 'Lithuania re-thinks its priorities as economic slowdown hits spending,' Europe's World, no. 20, p. 130.

Vogt, H. (2011), 'Estonia - ever more firmly in the nation-liberal course?' Baltic Rim Economies: Quarterly Review, no. 2, p. 40. 